\title{
PEMANFAATAN "WHATSAPP" SEBAGAI MEDIA KOMUNIKASI DOSEN DENGAN MAHASISWA BIMBINGAN SKRIPSI (Studi Analisis Deskriptif Pada Mahasiswa Ilmu Komunikasi Bimbingan Skripsi Universitas Dehasen Bengkulu Tahun 2016 )
}

\section{Oleh:}

\section{SRI NARTI}

\section{Dosen Prodi Ilmu Komunikasi FIS Universitas Dehasen Bengkulu}

\begin{abstract}
This study, entitled The Use of Whatsapp asa CommunicationMedia for studentsthesis guidance. This study aimed to describe the use of whatsapp as a media of communication betweenlecturers with students for thesis guidance. Therefore, it is interesting to examine how students communicate to the supervisor via whatsapp, includingthe consultations about the thesis guidance in performing routine tasks for the students' final thesis. The subjects were students of communication department who were doing thesis guidance numbered 72 people in 2016. The informants werethe lecturersof 10 peoplewho certainly connected with the researcher's whatsapp. The researcher used the theory of diffusion of innovation and social penetration theory to analyze the data. While the method used in this research was a field study where the researcher plunged into the field and the data were taken directly from the study sites. Furthermore, the researcherstudied literatures by finding material from books, articles, and scientific journals. With the phenomenological method, the researcher obtained an overview of the entire process experience of using whatsapp as a communication between the lecturers with the students. Through whatsapp interpersonal communication activities will be established as an alternative media when students and lecturers could not hold a thesis counseling process face to face. They will continue discussing without space and time. This is in order to anticipate a very shortthesis guidance schedule and lecturers' bustle. Students are assisted without waiting to hear from lecturers about guidance schedules, thesis discussion and others. Because the whatsapp discussion group has been formed by lecturers and students for thesis guidance. This is in order to motivate the students, improve academic activities such as paper consultation, and avoid students from stress feeling during thesis guidance.
\end{abstract}

Keywords: Whatsapp, Communication Media, Interpersonal Communication, Lecturers and Students.

\section{PENDAHULUAN \\ Latar Belakang}

Perkembangan teknologi yang semakin pesat di bidang komunikasi telah melahirkan ide-ide, inovasi, dan gagasan baru yang bertujuan untuk memperlancar proses komunikasi manusia agar menjadi lebih efektif.
Berkomunikasi tanpa dibatasi jarak adalah suatu revolusi di bidang komunikasi yang dapat manusia nikmati saat ini. Dahulu, komunikasi secara lisan berlangsung jarak dekat, akan tetapi saat ini teknologi melengkapi hal tersebut dengan tidak dibatasi oleh jarak dan waktu. Salah 
satu inovasi yang dapat mempermudah proses komunikasi tersebut adalah telepon selular atau yang biasa kita kenal dengan sebutan ponsel. Munculnya berbagai smartphone merupakan contoh dari kecanggihan teknologi dalam bentuk ponsel. Seperti Blackberry, Android, iPhone, Windows Phone dan lain-lain.

Nugraha (dalam Henson, 2012) menuliskan bahwa Indonesia masuk urutan ke-4 pengguna handphone terbanyak di dunia. Jumlah handphone di Indonesia diperkirakan mencapai sekitar 250.100.000 buah handphone dengan jumlah penduduk mencapai 237.556.363 jiwa. Sebuah survei yang dilakukan perusahaan Aweber menemukan bahwa siswa SMA dan mahasiswa serikat $90 \%$ pengguna facebook dan $93 \%$ pengguna telepon genggam atau handphone. Hal ini mengindikasikan bahwa handphone dan kebutuhan untuk berkomunikasi online sudah dikenal baik dan menjadi suatu kebutuhan masyarakat Indonesia.

Fenomena berkembangnya smartphone di Indonesia, juga turut mengundang fenomena lainnya bagi masyarakat pengguna telepon pintar (smartphone). Seperti yang kita ketahui pesan singkat yang lebih dikenal dengan SMS (Short Message Service) yang sudah mulai ditinggalkan. Dimana para pengguna smartphone sekarang beralih menggunakan aplikasi layanan chatting. Di Indonesia, aplikasi layanan chatting yang paling populer dan pertama yang berbasis Android, Blackberry, dan iPhone adalah Whatsapp. Aplikasi ini merupakan aplikasi berbayar bagi pengguna iPhone tetapi gratis bagi pengguna Android dan Blackberry. Selain itu aplikasi Whatsapp merupakan salah satu alat untuk berkomunikasi yang dimanfaatkan oleh semua kalangan, terutama di kalangan mahasiswa dan dosen yang tidak terlepas dari kebutuhan akan berkomunikasi. Selain mempermudah penyampaian pesan atau informasi secara efektif dan efisien secara waktu, media komunikasi juga berfungsi untuk menambah daya tarik informasi yang akan disampaikan sehingga semakin meningkatkan, memperbaiki dan memperbaharui taraf hidupnya seiring perkembangan peradaban yang semakin maju (Barata, 2003).

Media komunikasi adalah wadah atau sarana yang digunakan sebagai perantara untuk berkomunikasi satu dengan yang lainnya. Suranto (2011) mengatakan cara komunikasi interpersonal bermedia (tidak langsung) pada situasi tertentu dapat saja menjadi pilihan, misalnya dalam bentuk percakapan melalui telepon, email, surat menyurat, SMS, dan sebagainya. Pemanfaatan media komunikasi di era globalisasi saat ini membuat komunikasi pada situasi dan kondisi tertentu menjadi efisien dan memberikan latar belakang yang penting bagi perkembangan sosial, emosional, dan kognitif anak muda, terhitung pada sebagian besar waktu mereka (Pempek, Yermolayeva, dan Calvert, 2009).

Dahulu mahasiswa aktif menggunakan Sosial Media Facebook dan kini sebuah fenomena baru mahasiswa telah beralih menggunakan aplikasi Mobile Messaging (perpesanan) seperti Whatsapp, WeChat, dan Line. Sebagian mahasiswa menganggap bahwa Facebook sekarang sudah ketinggalan zaman, karena hanya bisa berkirim pesan teks dan gambar saja melalui perangkat seperti smartphone dan 
tablet serta tidak ada ruang privasi karena terlalu terbuka.

Pemanfaatan pesan singkat melalui perangkat telepon genggam adalah gaya berkomunikasi yang populer di era globalisasi saat ini. Sebuah penelitian yang dikutip dari www.vemale.com ("remaja lebih suka komunikasi 'jempol' daripada bicara", 2012) mengatakan bahwa rata-rata remaja mengirim pesan tertulis sebanyak 3.417 kali dalam satu bulan, atau rata-rata 7 kali setiap satu jam. Remaja putri lebih banyak menggunakan pesan tertulis, rata-rata mereka mengirim pesan sebanyak 3.952 kali setiap bulan, sedangkan remaja putra hanya mengirim pesan tertulis sebanyak 2.815 kali dalam satu bulan. Kegiatan mengirim pesan singkat dapat memenuhi kebutuhan kita untuk berkomunikasi kepada orang lain.

Teknologi juga merupakan faktor yang paling dominan dalam perubahan sistem pendidikan. Dengan teknologi maka komunikasi serta pembelajaran akan semakin efektif dan efisien. Komunikasi dan pembelajaran akan lebih menarik jika dikombinasikan dengan pemilihan media yang digunakan. Dosen dituntut agar dapat memberikan pembelajaran yang dapat memudahkan mahasiswanya dalam berkomunikasi dan memahami materi. Begitu pula hendaknya ketika proses bimbingan skripsi berlangsung. Mungkin dengan bimbingan melalui media, mahasiswa menjadi tertarik. Mengingat waktu dan intensitas bimbingan yang cukup singkat dan terbatas, oleh sebab itu sebagai dosen harus dapat mencari alternatif lain untuk meningkatkan intensitas komunikasi dan kualitas bimbingan. Salah satu caranya adalah dengan pemanfaatan media agar dapat memperlancar kegiatan akademis seperti konsultasi skripsi dan dapat memperbaiki proses bimbingan skripsi yang selama ini monoton. Karena bimbingan dilengkapi dengan menggunakan Whatsapp sebagai media komunikasi akan terasa lebih mudah, lebih menarik, metode bimbingan akan lebih bervariasi, sehingga mahasiswa tidak merasa bosan dan merasa termotivasi dalam menyelesaikan skripsi.

Mungkin dengan adanya media akan mempermudahkan mahasiswa dalam menjalani proses bimbingan skripsi. Metode bimbingan tidak semata-mata komunikasi verbal yang hanya melalui penuturan kata-kata oleh dosen, sehingga mahasiswa lebih banyak diskusi, sebab tidak hanya mendengarkan dosen bicara, melainkan mahasiswa juga terlibat dalam pertukaran informasi dengan dosen bahkan juga dengan teman sesama bimbingan. Selain itu mahasiswa dapat bertanya secara tertulis terhadap dosen mengenai kesulitan yang mereka jumpai tanpa harus bertemu langsung dengan dosen pembimbingnya. Baik melalui kontak individu maupun group Whatsapp yang komunitasnya adalah mahasiswa bimbingan skripsi.

Suranto (2011), dalam konteks komunikasi interpersonal, meskipun lebih dianjurkan melakukan komunikasi interpersonal secara langsung untuk meminimalisir resiko salah paham, namun penggunaan media dalam komunikasi interpersonal (komunikasi tidak langsung), seperti menggunakan SMS atau jejaring sosial, dirasa tetap efisien dilihat dari situasi dan kondisi tertentu. Transformasi gaya berkomunikasi menggunakan media ini dirasa sangat 
berpengaruh terhadap kebutuhan berkomunikasi manusia.

Menurut pendiri Whatsapp, Brian Acton, Indonesia merupakan salah satu dari lima negara yang menjadi pangsa pasar paling penting bagi perusahaan Whatsapp. Hal ini dapat dilihat dari tingkat pertumbuhan pengguna layanan Whatsapp dan juga jumlah pengguna layanan Whatsapp. Pengguna Whatsapp di perangkat Samsung tidak hanya di kalangan mahasiswa dengan mahasiswa saja tetapi ada juga mahasiswa dengan dosennya. Ada group khusus di kelompok tertentu ketika mereka bimbingan skripsi dalam berinteraksi satu dengan yang lainnya dan saling bertukar informasi, file, gambar, dan data karena langsung kepada orang yang bersangkutan atau orang yang ditujukan dalam menanyakan hal-hal yang kurang mengerti terkait masalah bimbingan skripsi dalam group Whatsapp Messenger.

Universitas Dehasen Bengkulu (UNIVED) merupakan salah satu universitas swasta di Bengkulu yang bagi masyarakat Bengkulu sudah tidak asing lagi. Universitas Dehasen memiliki 8 Fakultas yaitu Fakultas Ilmu Komputer, Fakultas Ekonomi, Fakultas Ilmu Sosial, Fakultas Pertanian, Fakultas Sastra, Fakultas Teknik, Fakultas Ilmu Pendidikan dan Fakultas Hukum. Salah satu program studinya adalah Ilmu Komunikasi, yang merupakan salah satu bagian dari Fakultas Ilmu Sosial dan Ilmu Politik (Statuta UNIVED Bengkulu). Universitas Dehasen sama halnya seperti Universitas lainnya yang memiliki skripsi sebagai syarat kelulusan untuk mendapatkan gelar sarjana strata satu. Skripsi adalah karya tulis ilmiah berdasarkan penyelidikan, pengamatan, dan pengumpulan data yang didapat dari suatu penelitian (Djuroto dan Bambang Supriyadi, 2005: 12). Sehingga semua program studi yang ada di Dehasen mewajibkan semua mahasiswanya untuk membuat skripsi yang tentunya dibantu oleh para dosen yang sudah mendapatkan kewenangan untuk membimbing skripsi. Adapun proses bimbingannya berbeda-beda karena setiap dosen memiliki cara dan karakter yang berbeda-beda pula. Yang jelas bimbingan skripsi dilakukan dengan komunikasi interpersonal. Komunikasi interpersonal merupakan komunikasi antara dua orang secara tatap muka, yang memungkinkan setiap orangnya menangkap reaksi dari setiap reaksi orang secara langsung, baik secara verbal ataupun nonverbal.

Adanya pola hubungan komunikasi antara mahasiswa dengan dosen menjadikan mahasiswa percaya dan patuh serta adanya penghormatan kepada dosen saat melaksanakan bimbingan skripsi, karena saat ini ada beberapa orang mahasiswa jurusan komunikasi yang sedang melaksanakan bimbingan skripsi, maka banyak pula terjadi interaksi sosial antara mahasiswa jurusan komunikasi dengan dosen pembimbing skripsi. Pada jurusan komunikasi di Universitas Dehasen, tugas utama seorang dosen adalah memberikan arahan tentang penelitian yang akan dilakukan mahasiswanya, menelaah dan menguji hasil penelitiannya. Arahan tersebut berupa topik penelitian, teori yang digunakan, kerangka pemikiran konseptual, hipotesis asumsi yang digunakan, model, analisis, metodologi penelitian dan kedalaman analisisnya. Berangkat dari fenomena komunikasi antara mahasiswa dengan dosen pembimbing yang tentu saja tidak hanya satu ataupun beberapa 
mahasiswa, namun banyak sekali mahasiswa jurusan komunikasi yang sedang melaksanakan bimbingan skripsi dan dosen pembimbing pun berbeda satu sama lain, dan masih banyak sekali mahasiswa yang belum menyelesaikan skripsi. Adapun total mahasiswa yang sedang menempuh skripsi sampai semester ini sebanyak 72 orang mahasiswa jurusan Ilmu Komunikasi.

Observasi awal penelitian menunjukkan bahwa mahasiswa sering merasa kecewa ketika dosen pembimbingnya tidak dapat dijumpai atau bahkan membatalkan waktu untuk bimbingan karena kesibukan dan pekerjaan sebagai seorang dosen. Intensitas pertemuan yang kurang dan metode bimbingan yang monoton hanya membuat mahasiswa kurang antusias terhadap bimbingan. Oleh sebab itu, sebagai seorang dosen sebaiknya mampu membuat mahasiswa tertarik dengan metode bimbingan yang diterapkan, karena akan mempermudahkan mahasiswanya ketika bimbingan. Di kampus sering kita jumpai mahasiswa yang sedang menunggu giliran bimbingan dengan dosen. Tetapi tak jarang dari mahasiswa harus menunggu tanpa ada kepastian kehadiran dosen. Meskipun mahasiswa sudah berusaha menelpon dosen tapi tidak diangkat dan mencoba sms tapi tidak dibalas. Di sisi lain, banyak juga dijumpai mahasiswa yang mengingkari janji untuk bimbingan skripsi dengan dosen pembimbing. Dosen telah siap membimbing tetapi mahasiswanya yang tidak jadi datang. Hal ini membuat komunikasi mahasiswa dan dosen kurang baik, tentunya akan menyebabkan lamanya waktu untuk mengerjakan skripsi. Hal terbaik yang dapat dilakukan adalah menjaga, memperbaiki, meningkatkan komunikasi yang harmonis antara dosen dan mahasiswa. Seperti mengadakan konsultasi bimbingan skripsi melalui media Whatsapp karena waktu pertemuan dengan dosen yang susah ditemui. Saat ini mahasiswa sangat beruntung sekali seiring dengan perkembangan teknologi ponsel, gadget, dan sejenisnya. Melalui teknologi ponsel mahasiswa bisa konsultasi lewat Telepon, SMS WA, BBM, dan Line. Yang terpenting adalah bagaimana pilihan komunikasi mahasiswa bisa sejalan dengan pilihan komunikasi dosen. Di Universitas Dehasen, dosen saat ini sedang menggunakan media Whatsapp untuk berkomunikasi dengan semua mahasiswa bimbingan skripsi, yang dilengkapi dengan komunitas grup WA sehingga Dosen dapat berinteraksi dengan seluruh mahasiswa bimbingan. Mahasiswa bisa melihat jadwal bimbingan yang diinformasikan oleh dosen di grup. Bagi dosen, media ini ikut membantu karena dapat memantau frekuensi bimbingannya dalam seminggu dan membuat jadwal nama-nama mahasiswa yang akan bimbingan.

Sebagai bagian dari proses penulisan skripsi, peran dosen sebagai pembimbing skripsi menjadi sangat penting karena merupakan tanggung jawab dosen untuk memastikan bahwa mahasiswanya mampu menyusun skripsi dengan baik hingga skripsi siap diujikan dan berkualitas. Hingga saat ini belum ada peraturan yang resmi berapa kali idealnya seorang mahasiswa menjalani bimbingan skripsi dengan para dosen pembimbingnya. Sejumlah keluhan dari para mahasiswa kerap muncul selama proses bimbingan skripsi. Misalnya, mahasiswa masih salah dalam menganalisis data atau 
kesalahan prosedur lainnya, mahasiswa sering mengulur-ulur waktu untuk menyelesaikan penelitiannya sehingga tiba waktu deadline banyak terdapat kesalahan, terdapat konflik antara salah seorang dosen pembimbing dengan mahasiswa selama perkuliahan, atau bahkan hubungan yang kurang harmonis antara dosen pembimbing I dan dosen pembimbing II. Hal ini semua akan menjadi masalah mahasiswa dalam menyusun skripsi. Untuk itu harus segera dicarikan solusi terbaiknya.

Saat mahasiswa memiliki jadwal bimbingan pada hari yang sudah ditetapkan secara rutin, sementara mahasiswa tersebut baru memasukkan bahan bimbingan atau skripsi yang telah diperbaiki. Mahasiswa memiliki waktu mengerjakan skripsi selama seminggu tetapi baru dikumpulkan $\mathrm{H}-1$. Dampaknya adalah dosen tidak memiliki waktu yang cukup untuk membaca atau memberikan feedback. Dalam proses seperti ini terjadi ketimpangan antara dosen dan mahasiswa. Mahasiswa memiliki waktu menulis skripsinya selama seminggu, sedangkan dosen hanya memiliki waktu membaca kurang dari sehari. Mahasiswa menilai dosen hanya memiliki tugas mengajar. Oleh sebab itu wajar jika mahasiswa menilai dosen mampu dan harus bisa membaca skripsi dalam waktu singkat. Mungkin tidak banyak mahasiswa yang mengetahui bahwa tugas atau kegiatan dosen tidak hanya sebatas mengajar di kelas, namun juga membimbing mahasiswa, melakukan kegiatan pengembangan pribadi yang terkait dengan bidang akademik, kegiatan pengabdian masyarakat, kegiatan penelitian, dan kegiatan penunjang akademik. Di sisi lain dosen juga memiliki tanggung jawab sebagai bagian dari keluarga ataupun masyarakat. Meskipun komunikasi melalui penggunaan aplikasi Whatsapp di kalangan mahasiswa Unived dan dosen terjadi di ruang virtual, tetapi komunikator dan komunikannya adalah orang yang nyata dan dampak dari aktivitas tersebut juga berwujud nyata. Perkembangan Trend Messenger tidak terlepas dari observasi terhadap tingkat pertumbuhan teknologi komunikasi yang ada di Dehasen melalui jumlah pengguna Whatsapp khususnya mahasiswa Ilmu Komunikasi yang sedang bimbingan skripsi Tahun 2016. Sudah sepantasnya kita memanfaatkan teknologi yang sedang berkembang saat ini untuk efisiensi waktu. Karena teknologi diciptakan untuk memudahkan manusia dalam menjalankan aktivitasnya. Dosen berusaha memberikan pelayanan bimbingan skripsi yang lebih baik kepada mahasiswanya. Adapun tujuan dari penelitian ini adalah untuk mendeskripsikan pemanfaatan Whatsapp sebagai media komunikasi dosen dengan mahasiswa bimbingan skripsi ilmu komunikasi Dehasen Bengkulu Tahun 2016.

\section{Teknologi Komunikasi}

Rogers dalam Lubis (2005 : 42) mendefinisikan teknologi komunikasi adalah peralatan-peralatan perangkat keras, struktur organisasi, dan nilai sosial dengan mana individu mengumpulkan, memproses dan terjadi pertukaran informasi dengan individu lain. Teknologi komunikasi mempunyai peranan penting dalam kehidupan berbangsa dan bernegara, karena dapat menjadi alat pemersatu bangsa dan masuk ke berbagai ranah kehidupan. Dampak dari teknologi 
komunikasi yaitu terjadinya perubahan pada tingkah laku individual yang meliputi pengetahuan, sikap, atau tindakan yang terjadi sebagai akibat dari penyampaian pesan komunikasi (Rogers, 1986).

\section{Whatsapp Messenger}

a. Merupakan aplikasi online chat yang kompatibel dengan beberapa jenis handphone, antara lain Iphone, Android, Blackberry, dan merk handphone Nokia. Akun whatsapp pada awalnya dibuat free, namun ada batasannya. Masa expire atau masa kadaluwarsa akun whatsapp adalah setahun. Jika ingin memakai lebih lama, bisa melakukan pembayaran sesuia ketentuan dari whatsapp.

b. Melakukan percakapan melalui menu chat, bisa meng-copy, mendelete, atau mem-forward pesan. Gambar yang terkirim bisa diforward. Selain itu juga dapat mengirim pesan suara maupun share lokasi keberadaan pengguna. Juga menyediakan fitur grup chat, dimana pengguna bisa mengumpulkan beberapa kontak untuk membuat sebuah grup chat.

\section{Media Komunikasi}

Media komunikasi adalah suatu alat yang dipergunakan untuk mempermudah penyampaian informasi dari seseorang kepada orang lain, untuk mencapai tujuan yang ditentukan. Menururt jenisnya, media komunikasi dapat dikelompokan dalam tiga macam, yaitu :

1. Media komunikasi berupa audio ( media komunikasi audio ), yaitu suatu alat komunikasi yang dapat ditangkap melalui alat pendengaran. Contohnya : radio, telepon, tape recorder, dan sebagainya.
2. Media komunikasi berupa visual ( media komunikasi visual), yaitu alat komunikasi yang ditangkap melalui alat penglihatan. Contohnya : surat, transparansi, chart atau grafik, dan lain-lain.)

3. Media komunikasi yang berupa audio visual ( media komunikasi audio visual ), yaitu alat komunikasi yang dapat dilihat dan dapat didengar. Contohnya : televisi, $\mathrm{VCD}$, layar lebar, internet, wawancara ( face to face ), kunjungan, dan sebagainya.

\section{Fungsi Media Komunikasi}

Fungsi media komunikasi yang berteknologi tinggi ialah sebagai berikut (Burgon \& Huffner, 2002);

a. Efisiensi penyebaran informasi

b. Memperkuat eksistensi informasi

c. Mendidik/ mengarahkan/ persuasi

d. Menghibur/ entertain/ joyfull

e. Kontrol sosial

\section{Tinjauan Tentang Klasifikasi} Sumber Belajar

a. Klasifikasi Sumber Belajar bukan hanya penyusunan daftar yang sederhana. Hal ini disebabkan sulitnya membuat batasan yang tegas dan pasti tentang perbedaan atau ciri-ciri yang terdapat pada sumber belajar. Uraian klasifikasi sumber belajar berdasarkan asal usul pengadaannya terbagi menjadi dua kategori, yaitu:

1).Sumber belajar yang dirancang (learning resources by design), yakni sumber belajar yang sengaja direncanakan, disiapkan untuk tujuan pembelajaran.

2).Sumber belajar yang dimanfaatkan (learning resources by utilization), yakni sumber belajar yang tidak 
direncanakan atau tanpa dipersiapkan terlebih dahulu, tetapi langsung dipakai guna kepentingan instruksional, diambil langsung dari dunia nyata.

3).Kedua macam sumber belajar tersebut, baik yang desain ataupun yang dimanfaatkan sama efektifnya dan dapat digunakan dalam kegiatan studi karena dapat memberi kemudahan belajar bagi mahasiswa. Berikutnya AECT (Association for Education Communication and Technology) mengklasifikasikan sumber belajar manjadi 6 jenis, yaitu:

a).Pesan (Messages), yaitu informasi yang ditransmisikan (diteruskan) oleh komponen lain berbentuk ide, fakta, arti dan data. Termasuk dalam kelompok ini adalah semua bidang studi atau mata kuliah yang diajarkan.

b).Manusia (Peoples), yaitu manusia yang bertindak sebagai penyimpan, pengolah, penyaji pesan. Contoh: guru, dosen, tutor, mahasiswa, dan lain-lain.

c).Bahan (Materials), yaitu perangkat lunak yang mengandung pesan untuk disajikan melalui penggunaan alat ataupun oleh dirinya sendiri. Contoh: transparansi, slide, film, video, buku, majalah, bahan instruksional terprogram dan lain-lain.

d).Alat (Tools), yaitu perangkat keras yang digunakan untuk penyampaian pesan yang tersimpan dalam bahan contoh: proyektor slide, overhead, video tape, radio, $\mathrm{TV}$, handphone, dan lain-lain.

e).Teknik (Techniques), yaitu prosedur atau acuan yang disiapkan untuk mempergunakan bahan, peralatan, orang dan lingkungan untuk menyampaikan pesan. Contoh: instruksional terprogram, belajar sendiri, demonstrasi ceramah, tanyajawab, dan lain-lain.

f) Lingkungan (Setting), yaitu situasi di sekitar dimana pesan disampaikan, lingkungan bisa bersifat fisik (gedung sekolah, kampus, perpustakaan, laboratorium, studio, dan lain-lain) maupun lingkungan non fisik (suasana belajar, dan lain-lain).

Dari uraian di atas penulis hanya meneliti poin kedua karena dari uraian diatas penulis hanya menggunakan media yang berhubungan langsung dengan sumber data yang diperoleh mahasiswa dari sebuah media online yaitu pemanfaatan whatsapp yang dapat dijadikan sebagai bahan untuk menyelesaikan bimbingan skripsi dengan dosen pembimbing skripsi.

\section{Komunikasi Antarpribadi}

Komunikasi Antarpribadi Interpersonal Communication ) adalah komunikasi antara individu-individu (Littlejohn, 1999 ). Bentuk khusus dari komunikasi antarpribadi ini adalah komunikasi yang melibatkan hanya dua orang secara tatap-muka, yang memungkinkan setiap pesertanya menangkap reaksi orang lain secara langsung, baik secara verbal ataupun nonverbal, seperti suami-isteri, dua sejawat, dua sahabat dekat, seorang 
guru dengan seorang muridnya, dan sebagainya. Jalaludin Rakhmat (2011) meyakini bahwa komunikasi antarpribadi dipengaruhi oleh :
a. Persepsi Interpersonal
b. Konsep Diri
c. Atraksi Interpersonal
d. Hubungan Interpersonal

\section{Efektifitas Komunikasi Antarpribadi}

Miftah Thoha (2007 : 187), mengemukakan pandangannya mengenai efektifitas komunikasi dalam uraian sebagai berikut :
a. Keterbukaan
b. Empati
c. Perilaku Suportif
d. Kepositifan
e. Kesamaan

\section{Teori Difusi Inovasi}

Artikel berjudul The People's Choice yang ditulis oleh Paul Lazarfeld, Bernard Barelson dan $\mathrm{H}$. Gaudet pada tahun 1944 menjdai titik awal munculnya teori difusi-inovasi. Menurut teori ini sesuatu yang baru akan menimbulkan keingintahuan masyarakat untuk mengetahuinya. Seseorang yang menemukan hal baru cenderung untuk menyosialisasikan dan menyebarkan kepada orang lain.

\section{Teori Penetrasi Sosial}

Teori Penetrasi Sosial dipopulerkann oleh Irwin Altman \& Dalmas Taylor (1973). Di sini dijelaskan bagaimana dalam proses berhubungan dengan orang lain, terjadi berbagai proses gradual, di mana terjadi semacam proses adaptasi di antara keduanya. Altman dan Taylor mengibaratkan manusia seperti bawang merah. Maksudnya adalah pada hakikatnya manusia memiliki beberapa layer atau lapisan kepribadian. Kedekatan hubungan terhadap orang lain, menurut Altman dan Taylor, dapat dilihat dari sejauh mana penetrasi seseorang terhadap lapisanlapisan kepribadian tadi.

\section{METODE PENELITIAN}

Penelitian ini menggunakan pendekatan deskriptif kualitatif. Metode ini dipilih karena peneliti berupaya menggambarkan fenomena komunikasi interpersonal dosen dengan mahasiswa pada bimbingan skripsi di Universitas Dehasen Bengkulu berdasarkan teori difusi inovasi dan teori penetrasi sosial. Tradisi fenomenologi menurut Creswell adalah "Studi dengan pendekatan fenomenologi dengan demikian, berupaya menjelaskan makna pengalaman hidup sejumlah orang tentang suatu konsep atau gejala, dalam hal ini komunikasi interpersonal yang ditunjukan oleh dosen dalam meningkatkan intensitas komunikasi pada bimbingan skripsi mahasiswa Ilmu Komunikasi Tahun 2016 di Universitas Dehasen Bengkulu.

Moleong menjelaskan bahwa fenomenologi tidak berasumsi bahwa peneliti mengetahui arti sesuatu bagi orang-orang yang sedang diteliti oleh mereka. Mereka berusaha untuk masuk ke dalam dunia konseptual para subjek yang ditelitinya sedemikian rupa sehingga mereka mengerti apa dan bagaimana suatu pengertian yang dikembangkan oleh mereka di sekitar peristiwa dalam kehidupan sehari-hari (Moleong, 2002: 9).

Sementara itu, Littlejohn menyebutkan, "Fenomenologi menjadikan pengalaman hidup yang sesungguhnya sebagai data dasar 
realitas" (Littlejohn, 1996: 204). Lebih jauh Littejohn menjelaskan, bahwa fenomenologi berarti membiarkan segala sesuatu menjadi nyata sebagaimana aslinya, tanpa memaksakan kategori-kategori peneliti terhadapnya. Seorang fenomenolog tidak pernah membuat hipotesis, tetapi menyelidiki dengan saksama pengalaman langsung yang sesungguhnya untuk melihat bagaimana tampaknya. Dengan metode fenomenologi ini peneliti akan menggambarkan implementasi dalam pemanfaatan whatsapp sebagai media komunikasi dosen dengan mahasiswa bimbingan skripsi.

Sasaran yang dicapai dalam penelitian ini adalah mahasiswa Ilmu Komunikasi Tahun 2016 yang sedang melakukan bimbingan skripsi di Universitas Dehasen Bengkulu. Penentuan informan dilakukan berdasarkan hasil pengamatan awal, agar dalam pembuatan pedoman wawancara harus benar-benar memperhatikan informan sehingga tidak terjadi salah pengertian karena kurang tepatnya pertanyaan yang disusun. Keabsahan data dari informasi harus dapat diandalkan mengingat dalam penelitian fenomenologi, informan merupakan kunci untuk mendapatkan data empiris. Agar data di lapangan menghasilkan informasi yang sesuai dengan fokus penelitian, maka penentuan informan dalam penelitian dibagi menjadi dua, yaitu:

1. Informan kunci yaitu dosen FISIP yang sedang bertugas sebagai pembimbing skripsi di prodi Ilmu Komunikasi Universitas Dehasen Bengkulu Tahun 2016

2. Informan pokok yaitu mahasiswa Ilmu Komunikasi yang sedang bimbingan skripsi Tahun 2016 dan menggunakan aplikasi whatsapp yang terhubung dengan kontak dosen pembimbing skripsi

Teknik penentuan sasaran dan informasi penelitian ini dilakukan melalui informan. Informan yang dipilih sesuai dengan kriteria penelitian. Adapun teknik penentuan sasaran dan informasi penelitian ini menggunakan teknik purposive sampling. Dengan menggunakan teknik purposive sampling, maka jumlah informan sudah ditentukan berdasarkan kriteria yang ditetapkan oleh peneliti. Dalam hal ini adalah mereka yang menggunakan aplikasi whatsapp pada handphone nya dan terutama mereka yang sedang terlibat dalam proses bimbingan skripsi Tahun 2016.

Dalam penelitian ini, data yang diperlukan meliputi data bersifat primer dan sekunder.

Data yang bersifat primer adalah data yang diperoleh secara langsung dari informan yang diteliti, baik yang dilakukan melalui observasi maupun wawancara. Pengamatan dilakukan dengan mendatangi informan penelitian untuk melakukan wawancara.

Wawancara dalam penelitian bertujuan untuk mengumpulkan keterangan dalam suatu masyarakat serta pendirian-pendirian mereka. Wawancara dilakukan untuk memperoleh informasi dari informan dan dapat menggunakan bantuan alat komunikasi seperti taperecorder atau handycam. Wawancara mendalam merupakan suatu cara mengumpulkan data atau informasi dengan maksud mendapat gambaran lengkap tentang topik yang diteliti.

Dokumentasi juga digunakan oleh peneliti untuk melengkapi dan memperkuat data yang telah diperoleh 
dari observasi dan wawancara. Data yang dimaksud di sini adalah dokumentasi berita, foto dan rekaman audio visual. Data yang meliputi arsiparsip dan monografi dipergunakan untuk menguatkan keberadaan data yang telah diperoleh di lapangan melalui proses observasi, dokumentasi dan wawancara.

Data tentang komunitas yang menggunakan aplikasi whatsapp didapatkan melalui :

1. Wawancara terhadap dosen dan mahasiswa Ilmu Komunikasi yang sedang bimbingan skripsi di Universitas Dehasen Bengkulu

2. Observasi terhadap penggunaan media komunikasi pada aplikasi handphone

3. Studi dokumentasi tentang pemanfaatan whatsapp

Lokasi penelitian akan dilakukan di Universitas Dehasen Bengkulu. Bimbingan belajar yang dipilih untuk observasi adalah bimbingan skripsi mahasiswa Ilmu Komunikasi Tahun 2016. Selain itu, pemilihan Universitas Dehasen Bengkulu juga dapat menggambarkan fenomena penelitian yang terjadi tentang pemanfaatan whatsapp sebagai media komunikasi dosen dengan mahasiswa bimbingan skripsi di Kota Bengkulu.

\section{HASIL PENELITIAN DAN PEMBAHASAN Hasil Penelitian}

Berdasarkan hasil observasi yang dilakukan peneliti dilokasi penelitian, peneliti melihat dan menganalisa serta mengamati bahwa penggunaan aplikasi whatsapp dikalangan dosen dan mahasiswa terus meningkat. Whatsapp juga disukai oleh para dosen dan mahasiswa Ilmu Komunikasi
Universitas Dehasen Bengkulu. Kehadiran aplikasi Whatsapp di smartphone juga dipergunakan oleh mahasiswa Unived Bengkulu sebagai media komunikasi. Alasan mahasiswa menggunakan aplikasi ini adalah karena memiliki fitur yang canggih, mahasiswa ingin mengikuti trend yang ada, dapat digunakan sebagai media bisnis online shop, dapat melakukan beberapa aktifitas sekaligus melalui ruang virtual dan dapat membantu interaksi mahasiswa dengan dosen ketika bimbingan skripsi. Hal ini dikarenakan kebutuhan berkomunikasi, interaksi, bertukar kabar dan informasi secara modern. Pemanfaatan whatsapp tidak hanya sebatas itu saja, karena hasil penelitian menunjukan bahwa para pengguna whatsapp memaknai media ini sebagai wadah untuk memudahkan komunikasi. Alasan mahasiswa menggunakan aplikasi ini adalah karena memiliki fitur yang canggih, mahasiswa ingin mengikuti trend yang ada, dapat digunakan sebagai media bisnis online shop, dan dapat melakukan beberapa aktifitas lainnya. Melalui ruang virtual, maka dapat membantu interaksi mahasiswa dengan dosen ketika bimbingan skripsi. Selain itu juga, aplikasi ini dijadikan sebagai tempat untuk promosi dan eksistensi diri. Menurut informan, mereka mengikuti perkembangan zaman dan memanfaatkan kecanggihan teknologi yang ada sekarang ini. Sedangkan untuk komunikasi yang terjadi antara mahasiswa dengan dosen menjadi lancar, serta dapat membuat hubungan mereka saling lebih mengenal satu sama lainnya. Dengan teknologi maka komunikasi serta pembelajaran akan semakin efektif dan efisien. Komunikasi dan pembelajaran akan lebih menarik jika dikombinasikan 
dengan pemilihan media yang digunakan. Dosen dituntut agar dapat memberikan pembelajaran yang dapat memudahkan mahasiswanya dalam berkomunikasi dan memahami materi. Begitu pula ketika proses bimbingan skripsi berlangsung. Bimbingan melalui media, membuat mahasiswa menjadi tertarik. Mengingat waktu dan intensitas bimbingan yang cukup singkat dan terbatas, oleh sebab itu sebagai dosen mereka mencari alternatif lain untuk meningkatkan intensitas komunikasi dan kualitas bimbingan. Salah satu caranya adalah dengan pemanfaatan media agar dapat memperlancar kegiatan akademis seperti konsultasi skripsi dan dapat memperbaiki proses bimbingan skripsi yang selama ini monoton. Karena bimbingan dilengkapi dengan menggunakan Whatsapp sebagai media komunikasi akan terasa lebih mudah, lebih menarik, metode bimbingan akan lebih bervariasi, sehingga mahasiswa tidak merasa bosan dan merasa termotivasi dalam menyelesaikan skripsi.

Pada dasarnya whatsapp merupakan salah satu aplikasi sosial media yang berupa chat secara real time karena dapat mengirim pesan dengan mudah. Aplikasi whatsapp memiliki fitur-fitur antara lain tanda pesan sukses terkirim, sudah diterima, dan sudah dibaca. Fitur ini hampir mirip dengan Blackberry yang menggunakan tanda $\mathrm{D}$ dan $\mathrm{R}$, sedangkan di whatsapp menggunakan tanda centang. Satu tanda centang (berwarna abu-abu) berarti pesan berhasil dikirim, dua tanda centang (berwarna abu-abu) berarti pesan telah diterima tapi belum dibaca, dan dua tanda centang berwarna biru berarti pesan telah dibaca. Jika tidak terhubung dengan koneksi internet, maka akan muncul tanda jam yang berarti pengiriman pesan tertunda. Whatsapp juga dapat mengirim file-file seperti:

1. Foto (langsung dari kamera, file manager dan media galery),

2. Video (langsung dari video kamera, file manager dan media galery),

3. Audio (langsung merekam suara, dari file manager, dari music galery),

4. Location (anda dapat mengirim lokasi anda dengan mengambil posisi anda dari google maps), dan

5. Contact (mengirim detail kontak dari phonebook).

Sementara untuk fitur yang lainnya adalah:

1. View contact artinya anda dapat melihat contact di phonebook, whatsapp juga muncul sebagai daftar contact di phonebook

2. Avatar yaitu anda tidak dapat mengganti avatar dari profile phonebook, apabila menggunakan sinkronisasi Facebook dengan Phonebook, maka avatar yang muncul adalah avatar Facebook

3. Selanjutnya add conversation shortcut yaitu dapat juga menambahkan shortcut conversation ke homescreen.

4. Email Conservation, yaitu anda pun dapat mengirim semua perbincangan melalui email

5. Copy/Paste: setiap kalimat perbincangan juga dapat dicopy, forward dan delete dengan menekan dan menahan kalimat tersebut dilayar.

6. Smile icon untuk menambahkan serunya perbincangan, anda pun dapat menambahkan emotion dengan banyak pilihan, seperti smile emotion, icon-icon seperti cuaca, binatang, tanaman, alat-alat musik, 
buku, kartu, mobil, bangunan, pesawat dan lain-lain.

7. Search yaitu fitur dasar setiap IM, Anda dapat mencari daftar contact melalui fitur ini.

8. Call karena pin whatsapp ini sama dengan no telp/hp teman, anda pun dapat melakukan panggilan langsung dari aplikasi whatsapp ini.

9. Whatsapp call yaitu pengguna bisa melakukan panggilan melalui whatsapp dengan koneksi internet.

10. Block digunakan untuk memblok kontak tertentu

11. Status seperti kebanyakan fitur IM, status juga hadir di whatsapp. Namun berbeda dengan BBM yang menampilkan update terbaru setiap ada perubahan status dari teman, whatsapp hanya menampilkan status dibawah nama teman, mirip dengan di Yahoo Messenger, anda dapat mengganti status yang sudah tersedia di whatsapp seperti available, busy, at school dan lain sebagainya.

Proses pengalaman sebuah media komunikasi yang berfungsi sebagai media penghubung antara dosen dengan mahasiswa yang menggunakan aplikasi whatsapp. Melalui whatsapp inilah kegiatan komunikasi interpersonal akan terjalin sebagai media alternatif ketika mahasiswa dan dosen tidak bisa mengadakan proses bimbingan skripsi secara tatap muka. Mereka akan tetap berdiskusi tanpa ruang dan waktu. Hal ini guna untuk mengantisipasi jadwal bimbingan skripsi yang sangat singkat dan kesibukan yang dimiliki oleh dosen. Mahasiswa sangat terbantu tanpa harus menunggu kabar dari dosen tentang jadwal bimbingan, diskusi tentang skripsi, dan lain-lain. Karena melalui whatsapp tersebut sudah dibentuk grup diskusi oleh dosen dengan mahasiswa bimbingan skripsi. Hal ini guna untuk memotivasi mahasiswa, memperlancar kegiatan akademis seperti konsultasi skripsi, dan menghindari mahasiswa dari rasa stress ketika melakukan bimbingan skripsi kepada dosen pembimbingnya.

Dengan adanya media akan mempermudahkan mahasiswa dalam menjalani proses bimbingan skripsi. Metode bimbingan tidak semata-mata komunikasi verbal yang hanya melalui penuturan kata-kata oleh dosen, sehingga mahasiswa lebih banyak diskusi, sebab tidak hanya mendengarkan dosen bicara, melainkan mahasiswa juga terlibat dalam pertukaran informasi dengan dosen bahkan juga dengan teman sesama bimbingan. Selain itu mahasiswa dapat bertanya secara tertulis terhadap dosen mengenai kesulitan yang mereka jumpai tanpa harus bertemu langsung dengan dosen pembimbingnya. Baik melalui kontak individu maupun grup Whatsapp yang komunitasnya adalah khusus mahasiswa bimbingan skripsi.

Menurut beberapa orang dosen, saat ini mereka sedang menggunakan media Whatsapp untuk berkomunikasi dengan semua mahasiswa bimbingan skripsinya, yang dilengkapi dengan komunitas grup WA sehingga dosen dapat berinteraksi dengan seluruh mahasiswa bimbingan. Mahasiswa bisa melihat secara langsung jadwal bimbingan yang diinformasikan oleh dosen di grup. Bagi dosen, media ini ikut membantu karena dapat memantau frekuensi bimbingannya dalam seminggu dan membuat jadwal nama-nama mahasiswa yang akan bimbingan. Whatsapp merupakan media komunikasi yang dapat digunakan dengan menggunakan kata- 
kata maupun suara dengan cara menekan tombol tertentu. Alasan inilah yang membuat para dosen dan mahasiswa memanfaatkan media ini sebagai media komunikasi karena mereka tidak harus bertemu tatap muka secara langsung dalam berkomunikasi untuk kegiatan bimbingan skripsi. Aplikasi whatsapp merupakan pengiriman pesan yang menggunakan koneksi wifi atau $3 \mathrm{G}$ untuk berkomunikasi tanpa harus mengeluarkan biaya tambahan. Dikalangan dosen dan mahasiswa, manfaat whatsapp sangat dirasakan karena dapat membantu mereka berkomunikasi ketika tidak dapat bertemu langsung untuk kegiatan bimbingan skripsi, akan tetapi mereka bisa berdiskusi melalui media whatsapp ini. Menurut informan dari mahasiswa, media whatsapp dimanfaatkan sebagai sarana chatting pengganti sms ketika mereka sedang mengikuti bimbingan skripsi, berdiskusi bersama dosen dan teman segrup, bisa bertukar informasi mengenai jadwal bimbingan dosen, dan dapat memperluas pertemanan juga sesama mahasiswa bimbingan skripsi lainnya. Melalui aplikasi ini juga, mahasiswa bisa berkirim video, foto, gambar, atau bahkan screenshout skripsi yang sedang di diskusikan dengan pembimbingnya. Hal ini digunakan sebagai alternatif jika dosennya sedang ada kegiatan sehingga tidak memungkinkan mereka untuk bertemu secara langsung. Jadi, melalui media ini mereka bisa chatting secara bersama-sama untuk berdiskusi langsung atau bahkan bisa menelpon jika ada percakapan mereka yang memang harus dibicarakn agar proses bimbingannya lebih jelas. Namun ada beberapa kelemahan yang dirasakan para pengguna karena aplikasi ini selalu meminta upgrade ke versi terbaru dan tidak dapat juga digunakan untuk mengirimkan file berupa word dan $p d f$ sehingga hal ini menjadi sedikit kendala ketika bimbingan namun mereka mempunyai alternatif lain untuk mengatasi hal tersebut, para mahasiwa bisa mengirimkan foto proposal atau skripsinya per bab kepada dosennya untuk dikoreksi. Dosen menanggapi dengan baik, karena menurut dosen mereka secara langsung dapat mengoreksi proposal atau skripsi para mahasiswanya secara langsung ketika mereka sedang berada dimana saja. Menurut mereka, hal ini sangat membantu mahasiswanya tanpa mereka harus menunggu kesiapan para dosenny sekedar bertemu untuk bimbingan. Tapi bukan berarti, dosen pembimbing dan mahasiswa tidak pernah bertemu secara langsung selama proses bimbingan. Merupakan solusi terbaru dan bagus, jika dosen dapat memanfaatkan perkembangan teknologi sekarang ini . Apalagi digunakan dalam koridor yang positif mungkin dapat memberikan contoh yang baik bagi para dosen lainnya. Intinya, para informan tertarik untuk memanfaatkan whatsapp yaitu untuk pengganti sms, agar dosen tetap dapat berkomunikasi dengan mahasiswa bimbingannya, dapat juga bertukar pikiran dengan temannya karena sudah dibuat grup khusus oleh dosen yang hanya diperuntukkan bagi mahasiswa yang sedang melaksanakan bimbingan skripsi dengan dosen. Berkomunikasi melalui whatsapp dirasa lebih cepat, simpel, mudah dioperasikan dan dapat terkoneksi secara langsung sehingga memungkinkan mereka berteman secara langsung dengan sesama penggguna whatsapp lainnya tanpa harus mengirim permintaan pertemanan seperti Facebook dan 
Blackberry yang harus diinvite pin terdahulu. Whatsapp berbeda dengan aplikasi lainnya karena whatsapp merupakan aplikasi lintas platform yang dapat digunakan disemua platform mobile seperti Android, Nokia, Blackberry dan Iphone.

\section{Pembahasan}

Berdasarkan hasil penelitian peneliti, melalui wawancara dengan 10 orang pengguna aplikasi Whatsapp didapatkan hasil bahwa Whatsapp digunakan sebagai media komunikasi sebagai sumber informasi. Rata-rata alasan para dosen dan mahasiswa memanfaatkan Whatsapp karena aplikasi Whatsapp selain memberikan informasi, juga dimanfaatkan sebagai sarana penghubung dan sarana alternatif antara dosen dan mahasiswa ketika bimbingan skripsi, sebagai hiburan seperti berbagi foto atau gambar tanpa batas ruang dan waktu, selain itu juga, karena tampilan dari aplikasi ini menarik dan simpel sesuai dengan kebutuhan masyarakat saat ini. Dan hal yang paling terpenting adalah melalui media ini, diantara pengguna akan tercipta proses komunikasi karena akan terjalin komunikasi interpersonal agar lebih dekat dan mudah untuk berkomunikasi dengan leluasa. Aplikasi Whatsapp dapat memberikan kemudahan dalam berinteraksi karena melalui grup whatsapp ini bisa menambah teman lebih banyak, dan yang pasti lebih mempermudah para pengguna untuk saling mengenal satu sama lainnya.

Whatssap digunakan untuk menjalin hubungan sosial diantara sesama orang-orang yang diinginkan dengan syarat mereka harus terhubung dengan aplikasi ini. Jika dilihat dari sudut pandang teori penetrasi sosial, maka diantara para pengguna aplikasi ini akan mengalami yang namanya proses adaptasi satu orang dengan yang lainnya. Sebagaimana dijelaskan dalam teori penetrasi sosial sudah dijelaskan bagaimana dalam proses berhubungan dengan orang lain, terjadi berbagai proses gradual. Hal inilah yang terjadi pada para pengguna aplikasi whatsapp. Bagaimana cara adaptasi mahasiswa dengan dosen pembimbingnya ketika berdiskusi tentang skripsinya di media online. Selain itu juga, mahasiswa dengan mahasiswa saling berinteraksi juga di dalam grup whatsapp mereka. Karena mereka harus memperhatikan yang namanya bahasa dan etika ketika berkomunikasi sebab melalui media komunikasi ini mereka bisa saling mengetahui secara langsung apa yang sedang dibicarakan.

Whatsapp tidak hanya digunakan untuk berkirim pesan saja, namun juga digunakan untuk menelpon, berkirim video dan audio tanpa ada batas ukuran. Para pengguna aplikasi ini juga membuat grup diskusi yang terdiri dari dosen dan mahasiswanya yang memang mempunyai kepentingan yang sama. Jika dilihat dari sudut pandang bahasa, banyak sekali bahasa yang tersedia disana seperti Bahasa Indonesia, Inggris, Jerman, Turki, Belanda dan lain-lain. Whatsaap grup merupakan sebuah ruang kelas virtual yang memfasilitasi setiap anggotanya dapat berkomunikasi dengan sesama anggota yang ada didalamnya.

Pesan-pesan yang diposting oleh informan beragam, seperti informasi mengenai jadwal bimbingan skripsi, perbaikan skripsi, kritik sosial, curahan hati hingga guyonan serta kalimat motivasi. Menurut mereka, hal tersebut hanya untuk pencitraan positif saja bagi para pengguna whatsapp. Media komunikasi whatsapp sebagai media yang mulai dilirik oleh banyak kaum, 
dan tentunya akan menimbulkan banyak persepsi tentang penggunaan media whatsapp sebagai media komunikasi di kalangan peserta didik, khususnya mahasiswa. Media seperti ini juga merupakan alat yang dapat digunakan oleh penggunanya ketika mereka melakukan hubungan sosial di dunia maya dengan tetap memperhatikan nilai-nilai moral dan etika dalam berkomunikasi. Pernyataan di atas didukung dengan Nasrullah, (2015:48) yang menyatakan bahwa:

"Situs jejaring sosial adalah media sosial yang paling populer. Media sosial tersebut memungkinkan anggotanya untuk berinteraksi satu sama lain. Interaksi terjadi tidak hanya pada pesan teks, tetapi juga termasuk foto dan video yang mungkin menarik perhatian pengguna lain. Semua posting (publikasi) merupakan real time, memungkinkan anggota untuk berbagi informasi seperti apa yang sedang terjadi".

Karena belajar adalah "suatu proses usaha yang dilakukan seseorang untuk memperoleh suatu perubahan tingkah laku yang baru secara keseluruhan, sebagai hasil pengalamannya sendiri dalam interaksi dengan lingkungannya" (Slameto, 2003:2). Dalam belajar agar memperoleh suatu perubahan atau peningkatan perlu adanya media. Media dalam proses belajar mengajar adalah "bagian yang tak terpisahkan dari proses belajar mengajar demi tercapainya suatu tujuan pendidikan pada umumnya dan tujuan pembelajaran' (Arsyad, 2013:2).

Dengan demikian media whatsapp yang dimanfaatkan oleh dosen dan mahasiswanya ketika bimbingan skripsi merupakan salah satu sarana dan terobosan baru di dalam dunia pendidikan saat ini. Pemanfaatan media whatsapp yang diakses dengan berbagai koneksi internet juga dapat meningkatkan partisipasi dalam kehidupan dunia maya. Melalui sebuah situs, dapat mengijinkan orang untuk membangun profil dirinya sebagai informasi untuk umum dan membuat daftar orang-orang yang menjadi temannya sekaligus juga dapat melihat secara langsung profil orang lain. Informasi yang diterima tergantung pada intensitas dari penggunaan media media tersebut, seperti jumlah waktu yang digunakan, frekuensi dan prioritas penggunaan dalam jenis media yang dikonsumsi. Ada beberapa manfaat yang dirasakan secara langsung dengan pemanfaatan whatsapp ini antara lain mendapatkan banyak informasi seperti informasi jadwal bimbingan dari dosen kepada mahasiswanya. Selain itu juga, manfaat lain yang dirasakan yaitu menjalin silaturahmi karena melalui whatsapp ini secara tidak langsung dapat menjalin silaturahmi meski terpisah jarak dan waktu baik dengan dosen, teman sesama grup maupun teman yang lainnya. Serta masih banyak manfaat lainnya yang dapat dirasakan oleh pengguna tergantung kebutuhannya masing-masing.

Penggunaan media whatsapp sebagai media komunikasi merupakan pemakaian media yang digunakan oleh dosen dan mahasiswanya untuk saling bersosialisasi dan berinteraksi, berbagi informasi maupun menjalin kerja sama untuk melakukan hubungan sosial di dunia virtual tersebut. Dapat diartikan bahwa mahasiswa memiliki kebutuhan dan memberi informasi maupun mendapatkan informasi karena mereka merasa terpenuhi akan kebutuhan informasi atau dengan kata lain kebutuhan didapat secara maksimal. 
Menurut dosen dan mahasiwa ilmu komunikasi Dehasen Bengkulu, kebutuhan mereka tentang alat yang digunakan untuk berkomunikasi dengan cepat, praktis dan dapat dijangkau menjadi salah satu alasan mereka memanfaatkan aplikasi whatsapp . Melalui whatsapp percakapan berlangsung lebih santai karen apembatas antara dosen dengan mahasiswa tidak terlalu nampak, tetapi mereka tetap memperhatikan yang namanya etika dalam berkomunikasi. Salah satunya grup yang dibuat khusus oleh dosen yang pesertanya adalah mahasiswa bimbingan skripsinya, grup ini dibentuk sebagai tempat diskusi dan pemberitahuan jadwal bimbingan yang dibuat oleh dosen. Keunggulannya adalah informasi bisa secara langsung dishare grup ataupun perindividu. Terlihat bahwa informasi langsung menyebar karena mayoritas mahasiswa aktif menggunakan aplikasi whatsapp ini.

Implikasi dari penelitian ini adalah berkomunikasi melalui aplikasi whatsapp dapat memberikan kemudahan dan kecepatan baik dalam proses bimbingan skripsi maupun informasi tentang jadwal bimbingan mahasiswa dengan dosennya. Perkembangan teknologi komunikasi telah mempermudah dan memberikan manfaat yang sangat berarti bagi kalangan mahasiswa Ilmu Komunikasi Dehasen Bengkulu yang sedang melakukan bimbingan skripsi karena melalui aplikasi whatsapp ini mereka tetap dapat berkonsultasi dengan dosen pembimbingnya apabila mereka sedang tidak dapat bertemu tetapi mereka tetap dapat berdiskusi. Jadi, ketika mereka memutuskan untuk bertemu, mahasiswa sudah mempunyai bekal ketika menghadap dosen pembimbingnya dan hanya meminta penjelasan saja lagi terkait skripsi yang sudah mereka buat. Dan biasanya, apabila hal ini sudah dilakukan, intensitas bimbingan dosen dengan mahasiswa secara tatap muka dapat berkurang karena intensitas dosen dengan mahasiswa di media whatsapp ini tergolong aktif. Terlihat dari respon yang diberikan oleh dosen secara langsung terhadap mahasiswanya ketika mereka bertanya.

\section{PENUTUP}

\section{Kesimpulan}

Berdasarkan hasil penelitian dan pembahasan di atas,dapat disimpulkan bahwa:

1. Tingkat penggunaan media sosial yang tinggi dapat dimanfaatkan untuk beragam keperluan proses komunikasi, salah satunya adalah aplikasi whatsapp yaitu sebagai tempat untuk berkomunikasi dan berdiskusi antara dosen dengan mahasiswa bimbingan skripsi.

2. Pemanfaatan whatsapp sebagai media komunikasi ketika bimbingan skripsi menjadi trend bagi dosen dan mahasiswa khususnya mahasiswa Ilmu Komunikasi Universitas Dehasen Bengkulu.

3. Whatsapp sebagai media komunikasi interpersonal yang banyak diminati oleh dosen dan mahasiswa melalui fitur-fitur menarik yang dimilikinya dapat memberikan solusi dan alternatif baru ketika bimbingan skripsi. Melalui whatsapp inilah kegiatan komunikasi interpersonal akan terjalin ketika mahasiswa dan dosen tidak bisa mengadakan proses bimbingan skripsi secara tatap muka. Mereka akan tetap berdiskusi tanpa ruang dan waktu. Hal ini guna untuk mengantisipasi jadwal 
bimbingan skripsi yang sangat singkat dan kesibukan yang dimiliki oleh dosen.

4. Aplikasi whatsapp sangat membantu dosen dan mahasiwa ketika bimbingan skripsi karena selain dapat mengirim pesan dengan mudah, fitur-fiturnya dapat mempermudahkan dosen untuk membuat grup sebagai media diskusi tentang skripsi, selain itu juga melalui fitur call whatsapp dapat menghemat pengeluaran untuk pembelian pulsa, karena fitur ini memang disediakan oleh whatsapp secara gratis untuk menelpon cukup membutuhkan koneksi ke internet. Mahasiswa sangat terbantu tanpa harus menunggu kabar dari dosen tentang jadwal bimbingan, diskusi tentang skripsi, dan lain-lain.

5. Whatsapp digunakan dosen dan mahasiswa untuk bertukar informasi terkait bimbingan skripsi. Hal ini dikarenakan fitur whatsapp yang simpel dan singkat dibanding media sosial lain. Melalui whatsapp para pengguna banyak menemukan informasi yang mereka butuhkan dan proses bimbingan skripsi dengan dosen tetap berjalan dengan lancar. Hal ini guna untuk memotivasi mahasiswa, memperlancar kegiatan akademis seperti konsultasi skripsi, dan menghindari mahasiswa dari rasa stress ketika melakukan bimbingan skripsi kepada dosen pembimbingnya.

\section{Saran}

1. Bagi Dekan Fakultas Ilmu Sosial dan Politik Universitas Dehasen Bengkulu, diharapkan hasil penelitian ini dapat dijadikan sebagai bahan dalam pengembangan akademik dan kurikulum yang mendatang dalam pembuatan regulasi tentang penggunaan media whatsapp sebagai alternatif media komunikasi antara dosen dan mahasiswa ketika bimbingan skripsi.

2. Bagi Ketua Jurusan Fakultas Ilmu Sosial dan Politik Universitas Dehasen Bengkulu, diharapkan hasil penelitian ini dapat dijadikan sebagai bahan untuk meningkatkan fasilitas internet yang lebih optimal lagi di kampus agar tujuan proses bimbingan skripsi dan proses belajar-mengajar dapat berjalan dengan lancar.

3. Bagi Dosen Fakultas Ilmu Sosial dan Politik Universitas Dehasen Bengkulu, diharapkan penelitian ini dapat dijadikan bahan referensi untuk menggunakan media whatsapp sebagai media komunikasi antara dosen dengan mahasiswa bimbingan skripsi, selain itu juga menjadikan media ini sebagai alternatif dalam proses pembelajaran dan memberikan inovasi dalam kegiatan belajarmengajar di kelas.

4. Bagi mahasiswa Fakultas Ilmu Sosial dan Politik Universitas Dehasen Bengkulu, diharapakan penelitian ini dapat digunakan sebagai media solusi, media alternatif belajar dan diskusi bimbingan skripsi dalam meningkatkan prestasi belajar mahasiswa.

5. Mahasiswa Ilmu Komunikasi Universitas Dehasen Bengkulu, telah menggunakan whatsapp untuk keperluan dan tujuan yang positif. Alangkah lebih baiknya jika hal tersebut diikuti oleh mahasiswa dan dosen-dosen lainnya agar interaksi tidak hanya terjalin dikampus saja. 
Sehingga mahasiswa dapat menyelesaikan penelitian skripsinya tepat waktu.

6. Bagi peneliti lainnya, diharapkan dapat mengembangkan hasil penelitian ini dengan mencoba meneliti objek yang lain serta pengaruh negatif dari penggunaan media whatsapp ini dalam kegiatan belajar maupun bimbingan skripsi.

\section{DAFTAR PUSTAKA}

AW Suranto. 2011. Komunikasi Interpersonal. Yogyakarta : Graha Ilmu

Arsyad, A. 2013. Media Pembelajaran. Jakarta: PT. Raja Grafindo.

Atep, Adya Barata. 2003. Dasar-Dasar Pelayanan Prima. Jakarta : Elex Media Kompetindo.

Burgon \& Huffner.2002. Human Communication. London : Sage Publication

Henson, J. M. \& French, R. 2012. The Polymerase Chain Reaction and Plant Disease Diagnosis. Annual Review of Phytopathology, $31: 81-109$

Littlejhon, Stephen W., 1996. Theories of Human Communication. Edisi ke-5, Belmont-California, Wadsworth.
Lubis, Zulkifli B. 2005. Kanalisasi Ketegangan Etnik dan Kompetisi Budaya dalam Sektor Publik. Jurnal Antropologi Sosial Budaya ETNOVISI, Vol.1, 2005, Medan : USU

Miftah Thoha. 2007. Kepemimpinan dalam Manajemen suatu Pendekatan Perilaku. Raja Grafindo Pustaka. Jakarta.

Moleong, Lexy J. 2002., Metodologi Penelitian Kualitatif. Bandung : Remaja Rosda Karya

Nasrullah, R. 2015. Media Sosial: Perspektif Komunikasi, Budaya, Dan Sosioteknologi. Bandung: Simbiosa Rekatama Media

Rakhmat, Jalaluddin. 2011., Psikologi Komunikasi. Bandung : Remaja Rosdakarya

Slameto, 2003. Belajar dan FaktorFaktor yang Mempengaruhinya. Jakarta: Rineka Cipta.

Yudit, Indrawaty. 2002. Motif Penggunaan Internet di Kalangan Mahasiswa Jurusan Komunikasi Penyiaran Islam Yogyakarta : Fakultas Dakwah IAIN Sunan Kalijaga

Yunindyawati. 2011. Pemakaian Internet di Kalangan Dosen FISIP UNSRI (Studi Tentang Pemanfaatan Internet dalam Kehidupan Akademis. Palembang 